All night I hear that dance, the flesh blistering white under the blue shell-bone. Surely I ate their poison, that forbidden membrane caging the sweet meat. Sleeping, my husband belongs to these ladies who root in my belly, tongs flashing, tongues bitter with the need for children. They admire my skin. I see it peel off: My lip will fall that way; the nose-bone grub forward. My great-grandmother's casket photograph showed a woman's chin caved-in like tub lard. Tonight the mirror is precise. I imagine everything, me, hare-lipped, earless, a thousand maggots at the brain.

\title{
IN IGNORANT CADENCE
}

The chemical tapestry of your brain amazes the heart of you,

all those ions \& neural protons

clicking into scenes or wishes. Your tongue is alive in your mouth like a slippery fish

so why can't you say anything? Even Philomela, throat staunched with rags, managed to shred her weaving fingers

until the thread equaled recklessness from once upon a time. The tongue of a bird is a delicacy-

yours, a distraction you never understood, a hopeless slab of muscle

forever wobbling on the edge of song. 